\title{
Study on the Operating Mode of Agricultural Demonstration Park in Laos Aided by China
}

\author{
Hao Yin \\ International Business School \\ Yunnan University of Finance and Economics \\ Kunming, China \\ yinhaoli@163.com \\ Ying Gao* \\ International Business School \\ Yunnan University of Finance and Economics
}

\author{
Kunming, China \\ gaoying921225@126.com
}

Huiping Liu

International Business School

Yunnan University of Finance and Economics

Kunming, China

hp953364780@126.com

\begin{abstract}
Since the end of 1980s, as China carried out opium poppy replacement in the northern Laos area with agricultural projects, Chinese government and investors have played an important role in the development of agricultural industry and investment in Laos. The survey methods and case methods were used in this text. The relevant conclusions have been drawn from cooperation modes and countermeasures. Firstly, the current development status of the Laos agriculture was analyzed. Secondly, the mode of China's assistance to the Laos agricultural demonstration park was studied from major forms, achievements, and major difficulties. Finally, conclusions and some suggestions were discussed, which is of great significance to the aid of China's agricultural development in Laos.
\end{abstract} Laos

Keywords—operation mode; agricultural demonstration park;

\section{INTRODUCTION}

China has always promoted the agriculture and rural development and alleviating poverty in other developing countries as a priority area for foreign aid.

By building farm, agricultural technology demonstration center, agricultural technology test and promotion station, water conservancy project, providing agricultural equipment and materials, dispatching agricultural experts and technicians, training agricultural talents for recipient countries, and so on, China is actively aiding to other developing countries to improve their agricultural production capacity and to deal with the food crisis.

Agricultural development is essential for developing countries to reduce poverty. Chinese agricultural experts not only teach agricultural technology in recipient countries, but also actively participate in the agricultural planning work of recipient countries and help recipient countries complete the work of promoting agricultural development. As a pillar industry in Laos, agriculture has always been one of the hot spots of foreign investment.

\footnotetext{
* Corresponding author
}

Laos has become a favorite target country for Chinese OFDI. In 2015, China's total investment in Laos has reached 5.65 billion US dollars, and there are 125 Chinese enterprises investing in Laos agriculture, of which 81 Yunnan enterprises, accounting for $64.8 \%$ of the total, and more than $50 \%$ of the total investment in Yunnan's foreign agricultural investment. Laos has grown up to the largest target market of OFDI of Yunnan. China's non-financial direct investment in Laos reached $\$ 1.36$ billion, increased by 36.2 percentage points compared with the previous year. The amount of OFDI to Laos from China ranked second in ASEAN countries. It achieved win-win in bilateral economic and trade cooperation and promoted common progress of two countries.

Scholars have little research on Chinese enterprises to invest in Laos. In view of the existing research results, there is a lack of empirical research on the research on agricultural investment model and the improvement effect and impact of the development of foreign enterprises in Laos on local communities and farmers' life. Compared with the positive practice of "going out" of Chinese agricultural enterprises, the academia lacks deep and comprehensive research on China ASEAN agricultural investment [2]. For the lack of related research, it can provide little theoretical guidance to investment activities of enterprise. Without research, enterprises are hard to development healthily. Without research, government lacks reliable information to make decision [1].

\section{The CurRent DeVelopment Status of}

\section{AGRICULTURE IN LAOS}

Agriculture is primary part of Laos' economy. Its agricultural construction has made outstanding achievements and provides a good model for the development of other developing countries. The agricultural production in Laos can be divided into 3 agro-ecological areas in the north, the middle and the south, of which there are 7 provinces in the northern agro-ecological area, 6 provinces in the central agro-ecological area and 4 provinces in the southern agro-ecological area. The 
northern region has a large population and developed industries, but the loss of labor force is relatively serious. The cultivated land area of rural areas has been reduced, and the level of agricultural development has lagged behind. The central region is the highest level of agricultural development, and the level of Agricultural Mechanization in the region is the highest in the country. The South relies on the shipping advantage of the Mekong River and the level of agricultural development is inferior to that of the central region.

Laos is rich in agricultural and forestry resources, which is incomparable to the other landlocked countries. The special natural climate moistens Laos and enables its people to plant various crops on the land. In addition, Laos has plenty of water and suitable temperature, which provides suitable conditions for the growth of trees and so on, so its forest resources are extremely rich. Laos has diversified terrain. There are mountains, plains, hills and so on. the water resources in the territory are rich, such as the Mekong River, the South Sang River and other rivers flowing through. Rivers nourish all things on the earth. It is important to emphasize that the soil resources in Laos are also more special, such as humus, red soil, and submersible soil. This kind of soil is more fertile and rich in minerals, which plays a positive role in the growth of crops. Laos is located in Southeast Asia. Neighboring countries belong to coastal countries. Although they are not in the sea, they are also obviously affected by the marine climate.

The agricultural products of Laos can be divided into three categories. they are food crops, cash crops and fruit. Rice, corn and potato are the most important food crops. Coffee, tobacco and tea are the pillar cash crops. The main fruits are tropical fruit, such as coconut, banana, yellow fruit, and so on. For livestock, pigs, cattle, sheep, chickens, ducks and geese are widely raised. Aquatic products are relatively abundant. Carp and catfish are favorite by resident.

Because of the unique geographical location, wet and rainy climate, the agricultural economy of the country is growing rapidly. At the same time, how to transform natural resources into economic resources, how to operate the scientific development strategy and promote the healthy development of agriculture are the urgent problem that Laos need to solve.

TABLE I. The MaIn Grain CROPS AND ECONOMIC CROPS IN THE PLANTING AREA AND YIELD

\begin{tabular}{|c|c|c|c|c|}
\hline & Crop & $\begin{array}{l}\text { Plantin } \\
\text { g area }\end{array}$ & $\begin{array}{c}\text { Single } \\
\text { output (ton } \\
\text { /hectare) }\end{array}$ & $\begin{array}{l}\text { Total } \\
\text { output }\end{array}$ \\
\hline 1 & Early rice & 68 & 3.76 & 245 \\
\hline 2 & Late rice & 9.4 & 4.79 & 45.2 \\
\hline 3 & $\begin{array}{c}\text { Upland } \\
\text { rice }\end{array}$ & 12.9 & 1.83 & 22.4 \\
\hline 4 & Corn & 17.6 & 4.82 & 84.9 \\
\hline 5 & Waxy corn & 2.5 & 3.25 & 8 \\
\hline 6 & Soybean & 1.3 & 1.54 & 1.95 \\
\hline
\end{tabular}

\begin{tabular}{|c|c|c|c|c|}
\hline 7 & Cassava & 1.1 & 14.7 & 15.3 \\
\hline 8 & Coffee & 6.5 & 0.88 & 4.6 \\
\hline 9 & Tobacco & 0.5 & 10.1 & 4.84 \\
\hline \multicolumn{5}{|c|}{ Data source: Ministry of agriculture of Laos }
\end{tabular}

\section{CHINA's ASSISTANCE TO AgRICUltURAL}

\section{DEMONSTRATION PARK IN LAOS}

\section{A. Main Forms}

The main forms of agricultural aid to Laos by China include aiding to construct farm, agricultural technology demonstration center, agricultural technology experiment station and extension station, construction of farmland water conservancy projects, agricultural machinery, agricultural products processing equipment and related agricultural materials, external assignment agricultural technicians and experts to teach technology of agricultural production and provide advice on agricultural development.

\section{B. Achievements}

Chinese investment enterprises are mainly concentrated in the northern part of Laos. The main business projects are agricultural cultivation, including rice, corn, sugarcane, castor, rubber, cassava, vegetable, tobacco and tropical fruit, etc. [6]. The key projects of the strategic cooperation between China and the Laos are as follows:

\section{Laos-Chongqing Comprehensive Agricultural Park}

The Laos-Chongqing comprehensive agricultural park is a demonstration project of agricultural cooperation established by the Chongqing of China and the Vientiane of Laos in 2004. The total area of the park is 5000 hectares. The project is located in Vientiane, the capital of Laos. The park is mainly divided into three stages. Agricultural experiments zone and supporting construction were developed in first stage. Crops, Livestock, Aquaculture are exploited in second stage. Agricultural production processing and related industry will be developed in third stage. Finally, the agricultural experiment park would be developed into a comprehensive park with agricultural and sideline products processing, and commercial circulation platform.

1) Yunnan-oudomxay agricultural science and technology demonstration park

Agriculture Department of Yunnan province and the agriculture and Forestry Department of the province of Oudomxay Province in Laos established the agricultural demonstration park in April 2007. After several years of development, 23 hybrid rice combinations, 5 conventional rice and 19 hybrid maizes were successfully introduced. 10 good varieties suitable for local application in Laos were screened and 21 varieties (combination) were selected for introduction and experiment, which popularized Chinese hybrid rice, hybrid corn, 206 thousand and $400 \mathrm{mu}$, and popularized 10 thousand $\mathrm{mu}$ of anti-cropping vegetables. $550 \mathrm{mu}$ of early rice and mechanized and high-quality rice planting were carried out [7]. 
2) China (Guangxi)-Laos experimental station for good crop varieties

In 2012, Guangxi Vocational and Technical College of Agriculture and the Lao Academy of agriculture and forestry jointly built the first experimental station for good crop varieties in ASEAN. The experimental station is divided into four zones: orchard area, vegetable area, rice maize area and leisure resort area. At present, the base has been planting 96 fine varieties in Laos, including 4 hybrid rices, 8 waxy corn and a batch of fine varieties of vegetables and fruits. According to the construction work plan of 2013, 135 varieties of crop varieties have been tested at the Vientiane station, of which 81 rice varieties, 51 maize varieties and 3 vegetable varieties are in good condition.

\section{3) Laos-Hunan (agriculture) economic and trade} cooperation zone

To promote the "going out" of Hunan enterprises, the Hunan provincial chamber of Commerce plans to join Laos and Hunan chambers of Commerce to build Laos Hunan (Agriculture) economic and trade cooperation zone in Laos. In order to make better use of the resources of the two countries, Hunan plans to establish a complete industrial chain from seed cultivation, planting, processing to sales and exporting to China. At the same time, according to the situation, the import trade of large agricultural products such as corn and cassava will be carried out.

\section{4) China-Laos cooperative drug substitution planting} project

In order to block the spread of drugs and AIDS from the source, Yunnan province has invested more than 500 million yuan since the implementation of opium poppy replacement in 1990s. It has helped the northern Burma and northern Laos to carry out opium poppy substitute for more than 62.5 ten thousand mu, and gradually from alternative planting to the higher-level transformation of alternative industries, alternative economy and alternative development. A total of about 40 ten thousand mu of poppy cultivation in this area was reduced. According to preliminary statistics, by the beginning of 2011, China had more than 60 enterprises in the north of Laos to carry out alternative planting and to develop alternative industries with an area of nearly 1 million $\mathrm{mu}$, with a total investment of about 600 million yuan. The replacement projects were all over the north of Laos, and nearly 40 varieties of sugarcane, rice, corn, cassava and tropical fruit were planted in the north. The generation of plantation has achieved positive effects in various stages.

\section{Major Difficulties}

Although China has a history of more than 10 years of agricultural assistance to Laos and has achieved some results, the development of agricultural demonstration park is slow and less influential than the cooperation in other fields. It has not really achieved the desired allocation of resources and promoted the development of agriculture, economy and social economy between China and Laos. According to the cooperation that has been carried out, to date, it is mainly the substitution of drug substitution planting, and the cultivated varieties are mainly concentrated on the planting of industrial raw materials such as sugarcane and rubber. There are also small areas of rice, vegetables, bananas, coffee and other crops grown through crops. The main forms of cooperation are limited to the mutual visits, investigations and some unpaid economic assistance between the government and the scientific research groups. The cooperation among enterprises is very few, and the overall cooperation pattern of Laos has not yet been formed. Agricultural cooperation is small in scale, small in number, narrow in scope and low in level.

\section{ANALYSIS OF OPERATION MODE OF CHINA'S FOREIGN AID Agricultural DEMONSTRATION PARK}

\section{A. Typical Model}

\section{1) The model of intergovernmental cooperation}

The mode of intergovernmental cooperation emphasizes the important role of the government in the management of modern agricultural parks. The government has unified planning, unified construction and unified management. It is directly managed by the government or government function departments of the site of the park to attract enterprises to participate in the market competition as the main body of the operation and camp. Under this management system, government provides a large amount of funds and land for the park. Government are responsible for constructing of infrastructure and facilities and made a series of policies to attract companies to invest in the park. The main agricultural park of the government is mainly from two aspects. On the one hand, the state departments, such as the Ministry of science and technology, the Ministry of finance, the State Planning Commission and other departments, have built the park in the form of project. The capital investment is mainly the matching funds between the State Department and the local government; On the other hand, there are parks that are subordinated to local farms, original farms, etc. Mainly capital investment are from Centre and local governments. The modern agricultural comprehensive development demonstration zone is located in Taizhou City of Jiangsu Province. It is a typical government-oriented park. The park management committee is the dispatched agency of government of Taizhou. The administrative committee has 6 functional organizations: office, organization, personnel, economic development, investment promotion, construction and Finance Bureau. The administrative committee consists of 3 service units, namely, the convenient service center, the labor and social security office, and the state asset management center. In addition, there are district offices and 4 neighborhood committees, which specifically manage the social work of all villages in the whole district [4].

\section{2) "Government + Enterprise" model}

This form refers to the government investment and construction of agricultural science and Technology Park, the completion of the park's infrastructure (e.g. water, electricity, road) and other supporting facilities. The government gradually withdrew from the management of the park and established the administrative committee of the park. The administrative committee of the park was responsible for attracting investment, property service and coordination, and making public rent to the community. The model can introduce 
enterprises to carry out constructing of functional area. The aim is to contract and manage the project. Enterprises need pay a certain rent to the relevant departments. On the one hand, we must pay certain rent to the relevant parks; on the other hand, it is directly linked to the farmers in the contracted area. The enterprise can sign contracts with the farmers. The farmers can sell the agricultural products. Also, the enterprise can organize farmers to produce through the form of contracts.

\section{3) "Company + Farmers" model}

Most of the agricultural demonstration park models are seed enterprises and agricultural technology companies. They usually rent land in Laos for demonstration planting. On the one hand, "adjust measures to local conditions": use local soil to cultivate seeds and seedlings. On the other hand, the local Laos farmers can understand the planting effect of these seeds and seedlings through intuitionistic way. The seed industry company can answer doubts according to the actual situation of the farmers and direct the promotion and sale to farmers in the field, so that the Laos farmers can produce the enthusiasm of buying. And technology companies, through the demonstration of production technology demonstration, management and management, let Laos farmers understand the benefits of the new technology will bring them, so that they are willing to use new technology to produce [3].

\section{4) Joint venture mode}

The joint venture mode is mainly based on the experimental base and is invested and built by scientific research and teaching units and local governments. The scientific research and teaching units combine the advanced agricultural technology and the production process and make the scientific and technological achievements limited to the laboratory quickly converted into productive force. The local government is responsible for building the experimental base, including the research equipment, the test field and so on, and provides funds to maintain the normal operation of the base. In this model, the research and production are two independent actors. They are common economic interests. Also, we should invest jointly in the research and development for the project. We should share risk and benefits. The agricultural park operate normally in the construction process [5].

5) Case analysis: Laos-China agricultural technology demonstration center in Oudomxay

a) Basic situation

China-Laos agriculture demonstration center project is located in the "Golden Triangle" area. Since 2010, Chinese agricultural experts have helped local farmers to master related planting techniques and promote the development of agricultural economy in northern Laos. The demonstration center also promoted the introduction of cultivated and cultured products to the Chinese market and realized the organic combination of technology promotion and market, which greatly improved the effect of alternative planting and technology promotion. At present, the agricultural demonstration center has reached an agreement with the Laos drug control center to provide agricultural skills training for drug addicts and to provide a certain number of seedlings for them to create conditions for their new life.
The model of "Supported by the Lao Government is Self-involvement of Farmers, and Operational Management of Chinese Enterprises", The technology demonstration park planted $550 \mathrm{mu}$. The park was carried out in Mena sang Kang village, Meng Sai County, Laos. From 2010 to 2014, Yinong Agriculture Import \& Export Co., Ltd. Imported 25,200 tons of agricultural products. The company achieved grain drying and handled more than 20,000 tons. It is effectively stimulated the bilateral agricultural trade and achieved a good situation of joint development.

\section{b) Achievements}

c) Radiation of the 9 provinces in the north

The agricultural demonstration center of Laos is the largest and most advanced agricultural demonstration center in Laos. It is the core of the agricultural extension of the Laotian Ministry of agriculture and forestry in all the provinces in the north, and the demonstration cultivation of $50 \mathrm{mu}$ dry rice, 150 mu of tea, $200 \mathrm{mu}$ of hybrid corn, $150 \mathrm{mu}$ of rubber, $20 \mathrm{mu}$ of vegetables, and the demonstration breeding of piglets, chickens and fish are the base areas. The seedlings of rubber, hybrid corn, tea, dry rice and vegetables were provided to Laos, and $9000 \mathrm{mu}$ of hybrid maize, $6000 \mathrm{mu}$ of rubber and $1250 \mathrm{mu}$ of upland rice were extended to 9 provinces in the north of Laos.

Through the guidance of more than 20 agricultural technical service stations in the surrounding area, the demonstration center promoted the establishment of the agricultural extension system in Laos and promoted the reform of the main body of agricultural extension in Laos, which made the extension of the Laos agricultural extension from the single government in the past to the government, the demonstration center, the agricultural technical service station and the cooperative, etc. The improvement of the Laos agricultural technology extension network enables the variety and technology of the demonstration center to be promoted in a timely and effective way to promote the development of the rural economy in the local and even the Laos north areas.

\section{d) Breeding good seeds to increase production}

The demonstration center, with the means of strengthening variety introduction, screened the varieties adapted to local planting conditions as the main push varieties, increased the varieties of Laos agricultural products, enriched the variety of Laos agricultural products, and greatly improved the production efficiency of the old Laos agricultural products. The demonstration center introduced China's fine hybrid maize varieties in Laos, selected the YNPC-1 and YNPC-2, which was the most suitable for Laos, and increased the yield of maize per hectare from 3 tons to 5 tons, and the introduction of Chinese Upland Rice Variety, 1 (Ludao-1), increased the single yield from 2.5 tons per hectare to 5 tons, and nearly 20 varieties of vegetable varieties were popularized. The cultivation of peppers, chili, tomato, beans, beans, long Solanum, pumpkin, cabbage and cabbage has achieved good results, enriches the supply of vegetables in the city, effectively alleviates the shortage of local vegetable production and product supply, and the high price of vegetables, and improves the local pork variety, The Laos has a long growth cycle and can only grow to 50 60 kilos at most, and the variety in the demonstration center will only take 4 to 5 months to grow to about $100 \mathrm{~kg}$, which is favored by the local 
people. It will promote the development of agricultural and rural economy, increase the income of farmers and ensure the smooth development of modern agriculture.

Through providing excellent rubber varieties and breeding, grafting, transplanting and cutting technology to Laos, the demonstration center has improved rubber planting and cutting technology in the province and Laos nationwide. So, the demonstration center has become a new agricultural R\&D center in Laos. A demonstration planting/breeding center have fine varieties. And a transformation center has technological achievements. It is enhanced the promotion capabilities. The capabilities are local agricultural technologies and the availability of improved varieties. It has promoted the ability of promoting the popularization of local agricultural technology and the ability of supply of good agriculture.

\section{e) Training beneficiaries widely}

According to the characteristics and practical needs of local agricultural development and the combination of theory and practice, the demonstration center has trained nearly 1500 local people in the form of theory and practice, and indirectly benefited 4000 farmers, which has enhanced the hematopoietic function of Laos' autonomous development. The training project covers a wide range of fields, covering the fields of agricultural technology and management such as planting, breeding, fisheries, processing of agricultural products, and the promotion of agricultural technology. The training topics include rubber grafting, gum cutting, rubber processing, hybrid maize seed production, hybrid corn planting, rice corn interplanting, tea picking processing, and vegetable planting. Taking into consideration that it is not easy for farmers to take part in training courses across regions, the training is carried out in the form of sending experts to lectures in various regions, eliminating the running of students, providing opportunities for students from poor families to take part in the curriculum, and creating opportunities for their poverty reduction.

\section{CONCLUSION}

The investment of Chinese enterprises to Laos agricultural development mainly through the mode of intergovernmental cooperation mode, "government + enterprise" model, "company + farmer" model, and the mode of joint venture mode. These models have effectively promoted the development of agricultural investment patterns towards diversification. China has established an agricultural demonstration park in Laos, with relatively advanced agricultural technology and abundant funds, but lack of experience in a certain agricultural demonstration park. Through the analysis and summary of the operation mode of the Laos agricultural demonstration park, it provides guidance for the development of the agricultural park in other developing countries, and it can be fully developed. Its radiation effect will drive the economic development of neighboring countries.

\section{ACKNOWLEDGMENT}

We would like to express our sincere gratitude to the director and staff of the Yunnan Business Representative Office in Laos, for supporting us in research with collection data. We also want to thank the anonymous reviewers for their comments.

\section{REFERENCE}

[1] H. Chong, "equality Introduction to agricultural modernization", Beijing: China Agriculture Press, 2000

[2] H.X Jie, H.S Qun, and H.L Yun, "Summary of the development status and research of modern agricultural gardens at home and abroad", Guangdong Agricultural Sciences, 2010 (7): 289-293.

[3] J.H Ping, and W.Y Nian, "Construction theory and mode exploration of agricultural science and Technology Garden", Beijing: Meteorological Press, 2002: 24-25.

[4] L Juan, "Practice study on the construction of cross border agricultural science and technology demonstration garden", Henan University of Technology, 2016.

[5] L.Q Cai, and L.Z Xin, "Research on operation mechanism of agricultural science and technology demonstration garden under market economy", Journal of Shandong Agricultural University (SOCIAL SCIENCE EDITION), 2006 (1): 99-101.

[6] L.W Ying, "Chinese and western agricultural cooperation", Business Forum.

[7] P.Ming, "Yunnan Laos agricultural cooperation research", Kunming University of Science and Technology, 2006. 